\title{
Genetic diversity and clonal relatedness of Aeromonas hydrophila strains isolated from hemorrhagic septicemia's cases in common Carp (Cyprinus carpio) farms
}

\author{
Z. M-A. Taha \\ Department of Pathology and Microbiology, College of Veterinary Medicine, Duhok University, Duhok, Iraq
}

\begin{tabular}{l} 
Article information \\
\hline Article history: \\
Received July 8, 2020 \\
Accepted August 27, 2020 \\
Available online October 1,2021 \\
\hline Keywords: \\
Aeromonas hydrophila \\
Fish farms \\
Genetic diversity \\
ERIC-PCR \\
\\
\hline Correspondence: \\
Z. M-A. Taha \\
zananvete@yahoo.com
\end{tabular}

\begin{abstract}
The objective of this study was to determine molecular typing and comparison analysis of 24 Aeromonas hydrophila isolated from the diseased fish with hemorrhagic septicemia in freshwater ponds and cage in Mosul and Duhok cities, Iraq. A total of 24 A. hydrophila isolates that were collected from various fish ponds and cage, were used in this study. Identification of isolates was made by the standard microbiological and molecular methods. ERIC-PCR was done with different primers to establish the genetic relationship between strains. ERIC-PCR typing showed that 24 strains of $A$. hydrophila were classified into 11 ERIC types (genotypes). Genotypes 9 and 7 represented the most prevalent clone. All $A$. hydrophila strains that were isolated from the same fish were genetically diverse. There was minimal genetic similarity between some strains which were retrieved from the same geographical source area. Also, some isolates from different geographic source area were showed a $100 \%$ genetically similar. Aeromonas hydrophila was genotypically heterogeneous and clonally dispersed among different fish ponds and cage in Mosul and Duhok cities, Iraq. Besides, one fish can be infected with more than one strains of $A$. hydrophila.
\end{abstract}

DOI: $10.33899 /$ ijvs.2020.127566.1511, (CAuthors, 2021, College of Veterinary Medicine, University of Mosul.

This is an open access article under the CC BY 4.0 license (http://creativecommons.org/licenses/by/4.0/).

\section{Introduction}

Nearly every aquatic ecosystem has had aeromonads, including chlorinated drinking water, untreated sewage, groundwater and contaminated and unpolluted rivers $(1,2)$. In addition, various domesticated animals may also have a role for the transmission of these bacteria through animal excretion (3). As a gastrointestinal and extra intestinal infection agent in humans, Aeromonas hydrophila was associated. Moreover, the primary cause of septicemia in many fish species is Aeromonas hydrophila such as common carp (Cyprinus carpio), tilapia (Oreochromis niloticus), hog (Lachnolaimus maximus), catfish (Siluriformes), salmon (Salmo salar) and many other freshwaters and marine species (4). One of the challenges in dealing with the risk of bacterial infection is to detect potential pathogens sources (5). The development of so-called bacterial source-tracking methods, tools to assign host source to environmental isolates of A. hydophila has been of significant interest (6). For these reasons, molecular epidemiology is necessary for controlling the spread of $A$. hydrophila between fish ponds (7). Recently, molecular typing methods are commonly used in microbial typing, leading to the rapid advancement of molecular biotechnology. Several studies have commonly used molecular typing methods for clinical and environmental Aeromonas strains as an epidemiological investigation (7-9). These include pulsed-field gel electrophoresis (PFGE), multi-locus enzyme electrophoresis (MLEE), and Enterbacterial repeated intergenic consensusPCR (ERIC-PCR) (4,10-12). These techniques are precise, reproducible, and easy to analyze the genome of bacteria, and to research the classification and recognition of phylogenetics (4). In addition, there are many strategies for investigating bacterial molecular diversity. ERIC-PCR has 
proven its predictive accuracy and is a fast and relatively simple technique which makes it useful for regular epidemiological studies $(9,13,14)$. Aeromonas hydrophila typing using ERIC-PCR is of easy application, low cost, good sensitivity and repeatability, and is ideal for bacterial genotyping and molecular epidemiology surveillance $(7,15)$. Unfortunately, there was only one study carried out in Iraq to determine the strain variation and investigate the clonal relatedness of A. hydrophila in clinical and environmental samples from diseased fish, which was used a phylogenetic tree analysis to compare between isolates of A. hydrophila (16). Therefore, this study was intended to investigate the genetic diversity and clonal relatedness of A. hydrophila strains isolated from diseased carps showing signs of hemorrhagic septicemia from different carp ponds and cage around Mosul and Duhok cities, Iraq.

\section{Materials and methods}

\section{Bacterial strains and genomic DNA extraction}

A total of 24 isolates of $A$. hydrophila were used in this study to investigate their clonal relatedness (cluster analysis) through ERIC-PCR fingerprinting. These isolates were previously recovered from lesions in different organs (liver, kidney, heart and lesions from the skin) of common carp showing signs of hemorrhagic septicemia farmed in different carp ponds and cage (including three ponds in Sumel district, one cage from Mosul dam and one pond in Khanke area) showed in (Table 1).

The isolated strains were identified by phenotypic methods (typical colonies on blood agar, pale colonies on MacConkey agar, Gram's stain, indole production test, oxidase test, catalase test and urease test) and also by molecular method (through PCR amplification of gcat gene) (17).

Some of those strains were obtained from the same fish but with different tissues. These isolates have been probably classified as genetically related in particular those isolated from the same fish and from the same geographical source area. All strains were grown in brain heart infusion broth (BHI) (Lab, M, UK) at $37^{\circ} \mathrm{C}$ and the stock cultures were performed and stored at $-20^{\circ} \mathrm{C}$ in $\mathrm{BHI}$ supplemented with $25 \%$ (v/v) glycerol (18).

DNA samples were extracted by thermal extraction method according to Taha and Yassin (19).

Briefly, $100 \mu \mathrm{l}$ of stock culture was inoculated onto MacConkey agar. Two to three 2-3 pure colonies were mixed with $200 \mu \mathrm{l}$ of sterile double distilled water. For at least 15 $\mathrm{s}$, the mixture was vortexed and directly heated at $95^{\circ} \mathrm{C}$ for $10 \mathrm{~min}$; the samples then cooled instantly by ice, the cooled suspension was centrifuged.

One hundred fifty $\mu \mathrm{l}$ supernatant was used as a template DNA for PCR. The purity and concentration of extracted DNA were examined using a nanodrop (Thermo Scientific, USA).
Table 1: The assigning of 24 A. hydrophila with their geographical source area and the fish organs

\begin{tabular}{lccc}
\hline $\begin{array}{l}\text { Strain } \\
\text { No. }\end{array}$ & $\begin{array}{c}\text { Strain } \\
\text { ID }\end{array}$ & $\begin{array}{c}\text { Geographical } \\
\text { Source area }\end{array}$ & $\begin{array}{c}\text { Fish's } \\
\text { organ }\end{array}$ \\
\hline 1 & S1a & Sumel pond 1 & Liver \\
$2^{\text {a }}$ & S1b & Sumel pond 1 & Liver \\
$3^{\text {a }}$ & S1c & Sumel pond 1 & Skin \\
$4^{\text {b }}$ & S2a & Sumel pond 2 & Skin \\
$5^{\text {b }}$ & S2b & Sumel pond 2 & Liver \\
$6^{\text {c }}$ & S2c & Sumel pond 2 & Skin \\
$7^{\mathrm{c}}$ & S2d & Sumel pond 2 & Heart \\
$9^{\mathrm{c}}$ & S2e & Sumel pond 2 & Liver \\
10 & S2f & Sumel pond 2 & Kidney \\
11 & S3a & Sumel pond 3 & Liver \\
12 & S3b & Sumel pond 3 & Liver \\
13 & S3c & Sumel pond 3 & Liver \\
$14^{\mathrm{d}}$ & S3d & Sumel pond 3 & Kidney \\
15 & S3e & Sumel pond 3 & Heart \\
16 & KHa & Khanke & Liver \\
17 & KHb & Khanke & Liver \\
18 & KHc & Khanke & Kidney \\
19 & KHd & Khanke & Heart \\
20 & KHe & Khanke & Heart \\
21 & KHf & Khanke & Kidney \\
22 & Ma & Mosul dam & Kidney \\
23 & Mb & Mosul dam & Heart \\
24 & Mc & Mosul dam & Kidney \\
\hline & Md & Mosul dam & Heart \\
\hline
\end{tabular}

The data of this table were derived from the previously published study (17). The same lowercase letter (a,b,c and d) parallel to strain numbers (in bold) indicates that these strains were isolated from the same fish. S: Sumel; KH: Khanke; M: Mosul dam.

\section{ERIC-PCR fingerprinting}

All A. hydrophila isolates were subjected to ERIC-PCR to identify similar strains and distinguish different strains using the primer sequences (ERIC1: 5'ATGTAAGCTCCTGGGGATTCAC-3' and ERIC2: 5'AAGTAAGTGACTGGGGTGAGCG-3') described by Versalovic et al. (20). The PCR assays were carried out in a total volume of $25 \mu \mathrm{l}$. Each reaction consisted of $2 \mu \mathrm{l}$ primers for each $10 \mathrm{pmol}, 12 \mu \mathrm{l}$ of hot start premix (Genedirex, Taiwan), $2 \mu 1$ of sample DNA 30-100 ng/ $\mu 1$ and nucleasefree water $9 \mu \mathrm{l}$ (Qiagen, Germany) up to $25 \mu \mathrm{l}$ (21). The PCR reaction was carried out carried using PCR system 9700 GeneAmp (Applied Biosystem, USA) according to the PCR program used by Bakhshi et al. (14). The first denaturation was for 5 min at $94^{\circ} \mathrm{C}$, next with 35 cycles of repeated steps each of $94^{\circ} \mathrm{C}$ for $1 \mathrm{~min}, 54^{\circ} \mathrm{C}$ for $1 \mathrm{~min}$, and $72^{\circ} \mathrm{C}$ for $5 \mathrm{~min}$. Finally, post PCR extension was done at $72^{\circ} \mathrm{C}$ for $10 \mathrm{~min}$. The Amplification of PCR products was loaded in $2 \%$ agarose gel prepared with $1 \times$ Tris-acetate-EDTA (TAE) buffer and stained by red safe DNA staining solution (GeNetBio, Korea). DNA ladder 100-bp (Genedirex, 
Taiwan) was used as a molecular size standard. An image was captured for data analysis.

\section{Data analysis}

An image with 24 wells representing all isolates of $A$. hydrophila, was firstly recorded manually for the presence or absence of DNA bands in gel obtained from ERIC-PCR and then finally analyzed using the GelJ software version 2.0 (available at https://sourceforge.net/projects/gelj/) to generate dendrogram (22). The clustering of the isolates was performed based on Unweighted Pair Group Method with Arithmetic Mean (UPGMA) analysis and Dice similarity coefficient. Isolates with a similarity coefficient equal to or above $90 \%$ (Similarity thresholds of $\geq 90 \%$ ) were clustered as the same genotype (15). Strains were clustered according to their origin of isolation (the same or different geographical source area) and strains which were isolated from the same fish but with different organs.

\section{Results}

According to the ERIC-PCR fingerprinting analysis (Figures 1 and 2) and depending on the differences in the number and size of ERIC sequences found in each isolate, the results showed that the similarity among A. hydrophila isolates was between $57-100 \%$ and all isolates were grouped in to11 genotypes (1-11) according to $90 \%$ cut off similarity coefficient, in which genotypes 9 and 7 represented the most prevalent clone and its variants among the isolates comprising $11 / 24 ; 45.8 \%$ of total isolates. Six strains were clustered in genotype 9 , followed by genotype 7 with 5 strains. On the other hand, each of genotype 1, 2, 5 and 6 have consisted of two strains. The remaining genotypes 3, 4, 8,10 and 11 were included of single strain only (Table 2 , Figure 2).

Interestingly, ERIC-PCR shows that all A. hydrophila strains that were isolated from the same fish were genetically diverse (all strains were showed a strong genotypic diversity) for examples, strain number 2 with 3 showed $57 \%$ genetic similarity, $87 \%$ similarity between strains 4 and 5, 77\% similarity of strains 7, 8 and 9, 77\% between strains 13 and 14 , as indicated by the Dice coefficient and shown with lowercase letters (Figure 2).

Regarding the geographical source area, some strains that were isolated from the same geographical source area, were genetically diverse (there was a very little genetic similarity between some strains which were isolated from the same geographical source area), for example, strains Sumel pond 1 (S1a, S1b and S1c; 57\% similarity), strains from Sumel pond 2 (S2a and S2d with S2b, S2c, S2f and S2e; 77\% similarity), strains from Sumel pond 3 (S3b with S3a, S3c, S3d and S3e; $68 \%$ similarity), strains from Khanke area ( $\mathrm{KHa}, \mathrm{KHb}$ and $\mathrm{KHc}$ with $\mathrm{KHd}, \mathrm{KHe}$ and $\mathrm{KHf} ; 57 \%$ similarity) and finally strains from Mosul dam (Mc and Md with $\mathrm{Ma}$ and $\mathrm{Mb} ; 64 \%$ ). In addition, some isolates from different geographical source area were $100 \%$ genetically similar (S1b, S2a and S3a), (S2d and S2e with KHb), (S2c and $\mathrm{S} 2 \mathrm{e}$ with $\mathrm{KHa}$ and $\mathrm{KHc}$ ), (S1c with $\mathrm{Md}$ ) and (KHe with Ma) (Figure 2, Table 3).

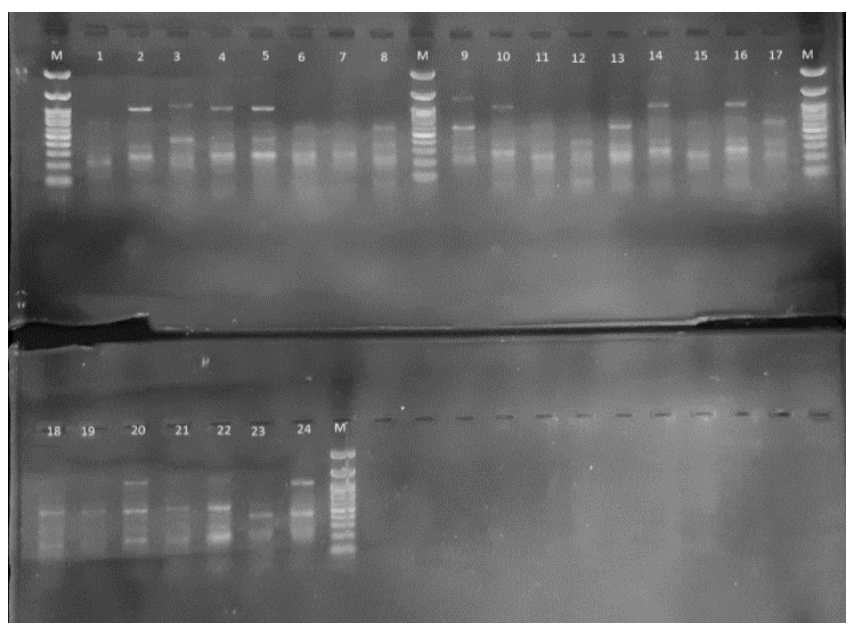

Figure 1: ERIC-PCR DNA fingerprint patterns of $24 A$. hydrophila strains isolated from common carp with hemorrhagic septicemia. Lane 1-24 represent studied samples.

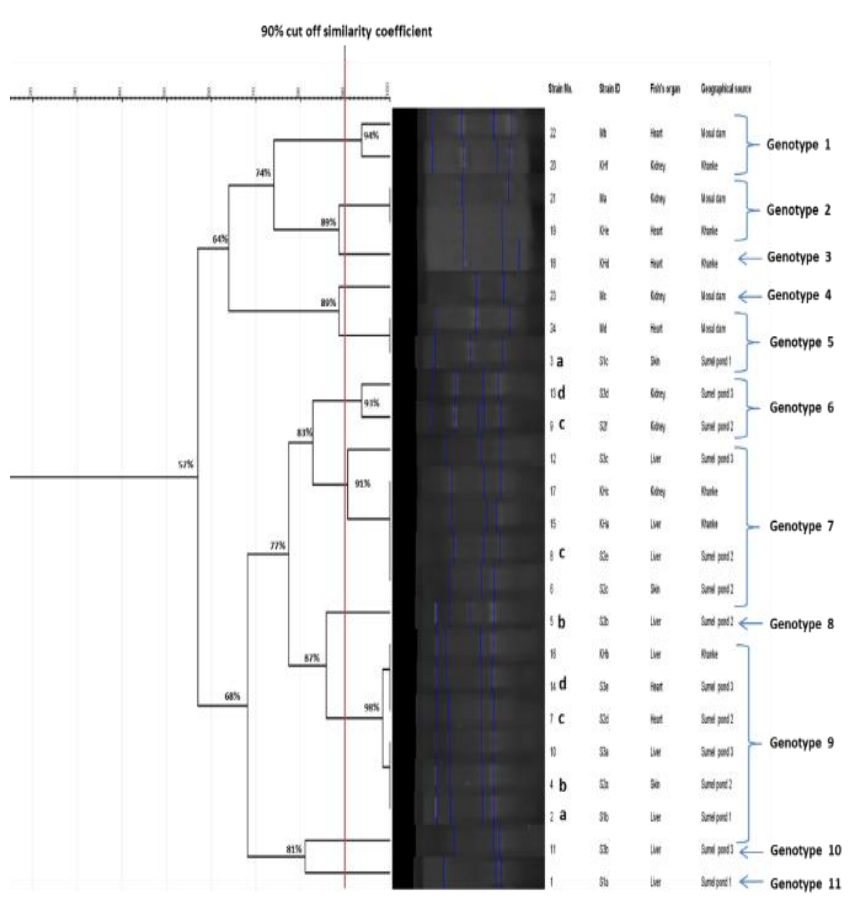

Figure 2: Dendrogram generated from ERIC-PCR showing banding pattern of 24 A. hydrophila strains isolated from common carp with hemorrhagic septicemia. The same lowercase letter (a,b,c and d) parallel to strain numbers indicates that these strains were isolated from the same fish. 
Table 2: Genotypic pattern of 24 A. hydrophila strains isolated from diseased fish

\begin{tabular}{|c|c|c|c|c|}
\hline Strain No. & Strain ID & Geographical area & Fish's organ & Genotypic pattern \\
\hline 20 & KHf & Khanke & Kidney & \multirow{2}{*}{ Genotype 1} \\
\hline 22 & $\mathrm{Mb}$ & Mosul dam & Heart & \\
\hline 19 & $\mathrm{KHe}$ & Khanke & Heart & \multirow{2}{*}{ Genotype 2} \\
\hline 21 & $\mathrm{Ma}$ & Mosul dam & Kidney & \\
\hline 18 & KHd & Khanke & Heart & Genotype 3 \\
\hline 23 & $\mathrm{Mc}$ & Mosul dam & Kidney & Genotype 4 \\
\hline 3 & S1c & Sumel pond 1 & Skin & \multirow{2}{*}{ Genotype 5} \\
\hline 24 & Md & Mosul dam & Heart & \\
\hline 9 & S2f & Sumel pond 2 & Kidney & \multirow{2}{*}{ Genotype 6} \\
\hline 13 & S3d & Sumel pond 3 & Kidney & \\
\hline 6 & S2c & Sumel pond 2 & Skin & \multirow{5}{*}{ Genotype 7} \\
\hline 8 & S2e & Sumel pond 2 & Liver & \\
\hline 12 & S3c & Sumel pond 3 & Liver & \\
\hline 15 & $\mathrm{KHa}$ & Khanke & Liver & \\
\hline 17 & $\mathrm{KHc}$ & Khanke & Kidney & \\
\hline 5 & S2b & Sumel pond 2 & Liver & Genotype 8 \\
\hline 2 & S1b & Sumel pond 1 & Liver & \multirow{6}{*}{ Genotype 9} \\
\hline 4 & S2a & Sumel pond 2 & Skin & \\
\hline 7 & S2d & Sumel pond 2 & Heart & \\
\hline 10 & S3a & Sumel pond 3 & Liver & \\
\hline 14 & $\mathrm{~S} 3 \mathrm{e}$ & Sumel pond 3 & Heart & \\
\hline 16 & $\mathrm{KHb}$ & Khanke & Liver & \\
\hline 11 & S3b & Sumel pond 3 & Liver & Genotype 10 \\
\hline 1 & S1a & Sumel pond 1 & Liver & Genotype 11 \\
\hline
\end{tabular}

S: Sumel; KH: Khanke; M: Mosul dam

Table 3: Percentages of genetic similarity between some stains within the same and different geographic source area

\begin{tabular}{lcc}
\hline Geographic source & Stains ID & Percentages of genetic similarity \\
\hline & S1a, S1b and S1c & $57 \%$ \\
Same geographic source & S2a and S2d with S2b, S2c, S2f and S2e & $77 \%$ \\
& S3b with S3a, S3c, S3d and S3e & $68 \%$ \\
& KHa, KHb and KHc with KHd, KHe and KHf & $57 \%$ \\
Mc and Md with Ma and Mb & $64 \%$ \\
Different geographic source & S1b, S2a and S3a & \\
& S2d and S2e with KHb & $100 \%$ \\
& S2c and S2e with KHa and KHc & \\
S1c with Md & \\
\hline
\end{tabular}

S: Sumel; KH: Khanke; M: Mosul dam

\section{Discussion}

This study was done in order to find the answers about these two questions. The first one, is that at which extend there was a genetic similarity between A. hydrophila strains from fish farms in a same and different geographical source area and the second question is about; is it possible that the same fish can be infected with two genetically diverse strains of A. hydrophila. A high genotypic pattern (11 genotypes out 24 strains) found in this study. This is an indication that a high genetic diversity exists within this bacterium as confirmed by Aguilera-Arreola et al. (8). In addition, Shaowu et al. (7), was also reported that there were a high genetic diversity of A. hydrophila strains from diseased carp, which they found three genotypic patterns among isolates of $A$. hydrophila in infected carp from different province in China.

This study found high genetic diversity among the strains isolated from the same geographical regions. This clonal variability of some isolates between the same fish pond and cage is an indication that there was a clonal expansion of certain strains of $A$. hydrophila has occurred in these fish farms (23). 
Moyer et al. (24), reported that A. hydrophila strains collected within the same city exhibited genetic variability. Conversely, Algammal et al. (9), said that all retrieved A. hydrophila strains from the same geographic area have no genetic diversity and all of them have identical profiles.

In this study, all A. hydrophila strains that were isolated from the same fish were genetically diverse. Suggesting that the coexistence of many A. hydrophila clones in the water of these ponds and also this is an indication that the fish were not infected with clonally related strains (25). Unfortunately, there have been no studies conducted in fish that would prove this situation, except one study which was carried out in human patient and found that two A. hydrophila strains isolated from the same patient but from different tissues were genetically diverse (26).

Another point of interest in our study was the determination of $100 \%$ genetic similarity among some strains isolated from different geographical source area. Suggesting that there was a single source of infection may be existing for these fish ponds and cage. Genetic stability between different strains can be related to physiological adaptation to the environments that they exist (27). AguileraArreola et al. (8), also found some strains of A. hydrophila isolated in different geographical locations, were clonally related since they displayed identical profiles $100 \%$ similarity. In this study, there was a high genetic diversity between stains which were isolated from fish cage in Mosul dam, when compared to the similarity of strains within fish ponds, this could be due to the differences in microbial contents of these two environments which in turn may be due to the presence of open system in fish cages that can be freely accessed by genetically diverse bacteria through continuous water re-circulation (28).

\section{Conclusion}

The data from this study found that $A$. hydrophila was genotypically heterogeneous and clonally dispersed among different fish farms in Mosul and Duhok cities, Iraq. Also, this study shows that one fish can be infected with more than one strains of A. hydrophila.

\section{Acknowledgements}

This study was supported by Duhok Research Centre (DRC), College of Veterinary Medicine, University of Duhok, Iraq.

\section{Conflict of interest}

No conflicts regarding publication of this manuscript.

\section{References}

1. Topic Popovic N, Kazazic SP, Strunjak-Perovic I, Barisic J, Klobucar RS, Kepec S, Coz-Rakovac R. Detection and diversity of aeromonads from treated wastewater and fish inhabiting effluent and downstream waters. Ecotoxicol Environ Saf. 2015;120:235-42. DOI: 10.1016/j.ecoenv.2015.06.011

2. Huddleston JR, Zak JC, Jeter RM. Antimicrobial susceptibilities of Aeromonas spp. isolated from environmental sources. Appl Environ Microbiol. 2006;72(11):7036-42. DOI: 10.1128/AEM.00774-06

3. Zubairi RB. Genetic detection to Aeromonas hydrophila proteolytic activity in milk samples (cows, buffaloes and goats) in Basra governorate. Iraqi J Vet Sci. 2020;34(2):253-8. DOI: 10.33899/ijvs.2019.125888.1174

4. Janda JM, Abbott SL. The genus Aeromonas: Taxonomy, pathogenicity, and infection. Clin Microbiol Rev. 2010;23(1):35-73. DOI: $\underline{10.1128 / C M R .00039-09}$

5. Kenta ML, Feistb SW, Harperc C, Hoogstraten-Millerd S, Lawe JM, Sánchez-Morgadof JM, Tanguayg RL, Sanders GE, Spitsbergena JM, Christopher M, Whipps CM. Recommendations for control of pathogens and infectious diseases in fish research facilities. Comp Biochem Physiol C Toxicol Pharmacol. 2009;149(2):240-248. DOI: 10.1016/j.cbpc. 2008.08.001

6. Harwood VJ, Staley C, Badgley BD, Borges K, Korajkic A. Microbial source tracking markers for detection of fecal contamination in environmental waters: Relationships between pathogens and human health outcomes. FEMS Microbiol Rev. 2014;38(1):1-40. DOI: 10.1111/1574-6976.12031

7. Shao-wu L, Di W, Hong-bai L, Tong-yan L. Molecular Typing of Aeromonas hydrophila Isolated from Common Carp in Northeast China. J Northeast Agric Univ (English Ed) 2013;20(1):30-6. DOI: 10.1016/S1006-8104(13)60005-7

8. Aguilera-Arreola MG, Herna'ndez-Rodrı'guez C, Zuniga G, Figueras MJ, Castro-Escarpulli G. Aeromonas hydrophila clinical and environmental ecotypes as revealed by genetic diversity and virulence genes. FEMS Microbiol Lett. 2005;242:231-40. DOI: 10.1016/j.femsle.2004.11.011

9. Algammal AM, Mohamed MF, Tawfiek BA, Hozzein WN, El Kazzaz WM, Mabrok M. Molecular typing, antibiogram and PCR-RFLP based detection of Aeromonas hydrophila complex isolated from Oreochromis niloticus. Pathogens. 2020;9(3):1-15. DOI: 10.3390/pathogens 9030238

10. Soler L, Figueras MJ, Chacón MR, Guarro J, Martinez-Murcia AJ. Comparison of three molecular methods for typing Aeromonas popoffii isolates. Antonie Van Leeuwenhoek. 2003;83:341-349. DOI: 10.1023/A:1023312415276

11. Borchardt MA, Stemper ME, Standridge JH. Aeromonas isolates from human diarrheic stool and groundwater compared by pulsed-field gel electrophoresis. Emerg Infect Dis. 2003;9(2):224-8. DOI: 10.3201/eid0902.020031

12. Minana-Galbis D, Farfan M, Fuste MC, Loren JG. Genetic diversity and population structure of Aeromonas hydrophila, Aer. bestiarum, Aer. salmonicida and Aer. popoffii by multilocus enzyme electrophoresis (MLEE). Environ Microbiol. 2004;6(3):198-208. DOI: 10.1111/j.1462-2920.2004.00554.x

13. Ranjbar R, Karami A, Farshad S, Giammanco GM, Mammina C. Typing methods used in the molecular epidemiology of microbial pathogens: A how-to guide. New Microbiol. 2014;37(1):1-15. [available at]

14. Bakhshi B, Afshari N, Fallah F. Enterobacterial repetitive intergenic consensus (ERIC)-PCR analysis as a reliable evidence for suspected Shigella spp. outbreaks. Brazilian J Microbiol. 2018;49(3):529-33. Doi: 10.1016/j.bjm.2017.01.014

15. Zarifi E, Ghazalibina M, Mansouri S, Morshedi K, Pourmajed R, Arfaatabar M. Molecular typing of Acinetobacter baumannii clinical strains by enterobacterial repetitive intergenic consensus polymerase chain reaction (ERIC-PCR). Gene Reports. 2020;18:1-5. DOI: 10.1016/j.genrep.2019.100542

16. Abdulhasan GA, Alattar NS, Jaddoa NTM. Comparative study of some virulence factors and analysis of phylogenetic tree by $16 \mathrm{~S}$ rDNA Sequencing of Aeromonas hydrophila isolated from clinical and environmental samples. Iraqi J Sci. 2019;60(11):2390-7. DOI: $\underline{10.24996 / i j s .2019 .60 .11 .9}$ 
17. Taha ZM, Sadiq ST, Khalil WA, Muhammad-Ali KY, Yosif HS, Shamil HN. Investigation of gcat gene and antibiotic resistance pattern of Aeromonas hydrophila isolated from hemorrhagic septicemia's cases in fish farms. Iraqi $\mathbf{J}$ Vet Sci. 2021;35(2):375-380. DOI: 10.33899/ijvs.2020.126876.1405

18. Aulet De Saab OC, De Castillo MC, De Ruiz Holgado AP, De Nader OM. A Comparative study of preservation and storage of Haemophilus influenzae. Mem Inst Oswaldo Cruz. 2001;96(4):583-6. DOI: 10.1590/S0074-02762001000400022

19. Taha ZM, Yassin NA. Prevalence of diarrheagenic Escherichia coli in animal products in Duhok province, Iraq. Iran $\mathrm{J}$ Vet Res. 2019;20(4):255-62. DOI: 10.22099/ijvr.2019.5502

20. Versalovic J, Koeuth T, Lupski JR. Distribution of repetitive DNA sequences in eubacteria and application to finerpriting of bacterial enomes. Nucleic Acids Res. 1991;19(24):6823-31. DOI: 10.1093/nar/19.24.6823

21. Saleem S, Bokhari H. Resistance profile of genetically distinct clinical Pseudomonas aeruginosa isolates from public hospitals in central Pakistan. J Infect Public Health. 2020;13(4):598-605. DOI: 10.1016/j.jiph.2019.08.019

22. Heras J, Domínguez C, Mata E, Pascual V, Lozano C, Torres C, Zarazaga M. GelJ - a tool for analyzing DNA fingerprint gel images. BMC Bioinformatics. 2015;16(1):1-8. DOI: 10.1186/s12859-015$\underline{0703-0}$

23. Hossain MJ, Sun D, McGarey DJ, Wrenn S, Alexander LM, Martino ME, Xing Y, Terhune JS, Liles MR. An Asian origin of virulent Aeromonas hydrophila responsible for disease epidemics in united states-farmed catfis. MBio. 2014;5(3):1-7. DOI: 10.1128/mBio.0084814

24. Moyer NP, Luccini GM, Holcomb LA, Hall NH, Altwegg M. Application of ribotyping for differentiating aeromonads isolated from clinical and environmental sources. Appl Environ Microbiol. 1992:58(6):1940-4. DOI: 10.1128/AEM.58.6.1940-1944

25. Li XM, Zhu YJ, Ring ø E, Yang DG. Prevalence of Aeromonas hydrophila and Pseudomonas fluorescens and factors influencing them in different freshwater fish ponds. Iran J Fish Sci. 2020;19(1):111-24. DOI: $10.22092 /$ ijfs.2019.120174

26. Grim CJ, Kozlova EV, Ponnusamy D, Fitts EC, Sha J, Kirtley ML, van Lier CJ, Tiner BL, Erova TE, Joseph SJ, Read TD, Shak JR, Joseph SW, Singletary E, Felland T, Baze WB, Horneman AJ, Chopra AK. Functional genomic characterization of virulence factors from necrotizing fasciitis-causing strains of Aeromonas hydrophila. Appl Environ Microbiol. 2014;80(14):4162-83. DOI: 10.1128/AEM.0048614

27. Talon D, Dupont MJ, Lesne J, Thouverez M, Michel-Briand Y. Pulsedfield gel electrophoresis as an epidemiological tool for clonal identification of Aeromonas hydrophila. J Appl Bacteriol. 1996;80(3):277-82. DOI: 10.1111/j.1365-2672.1996.tb03220.x

28. Wamala SP, Mugimba KK, Mutoloki S, Evensen O, Mdegela R, Byarugaba DK, Sorum H. Occurrence and antibiotic susceptibility of fish bacteria isolated from Oreochromis niloticus (Nile tilapia) and Clarias gariepinus (African catfish) in Uganda. Fish Aquat Sci. 2018;21(6):1-10. DOI: 10.1186/s41240-017-0080-x

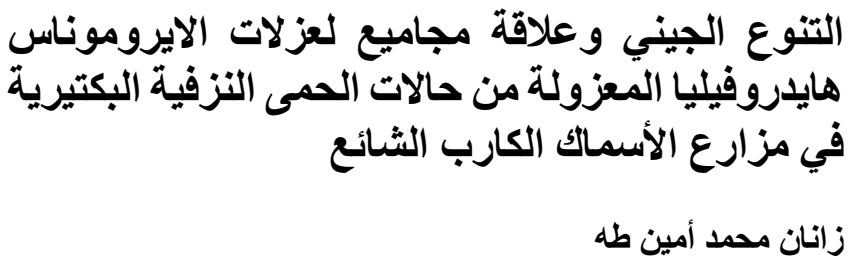

فرع الأمر اض و الأحياء المجهرية، كلية الطب البيطري، جامعة دهوك،

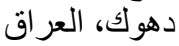

الخلاصة

الهدف من هذه الدراسة هو تحديد التمييز الجيني و المقارنة بين أربعة

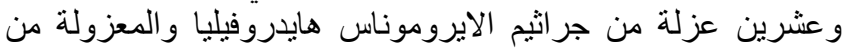

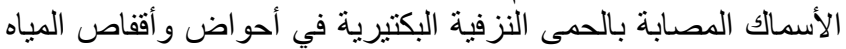

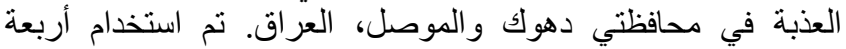

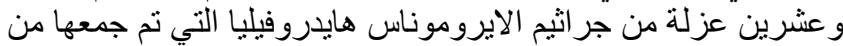

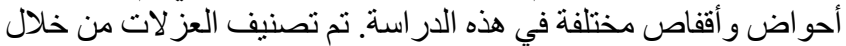

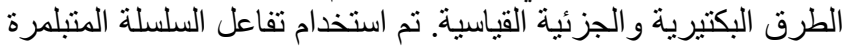

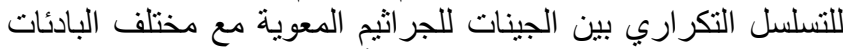

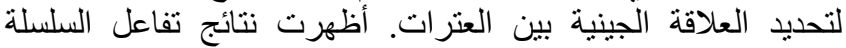

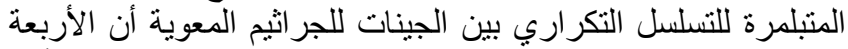

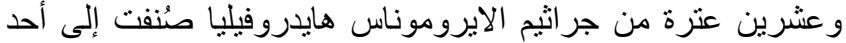

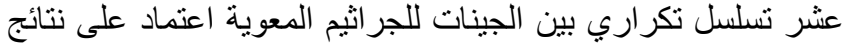
تفاعل السلسلة المتبلمرة للتسلسل التكر اري بين التين الجينات للجر اثيم المعوية.

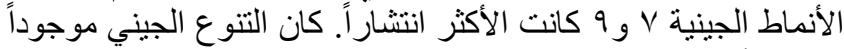

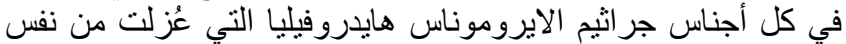

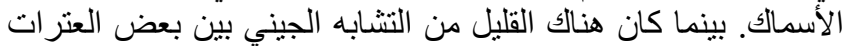

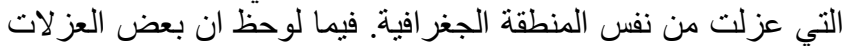

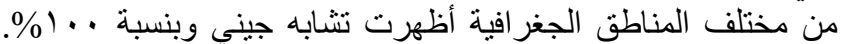
بينت الدراسة أن جراثيم الايروموناس هايدروفيليا غير متجانسة جينياً

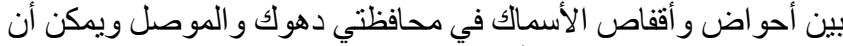
تصاب السمكة الواحدة بأكثر من عزلة من جراثيم الثيم الايروموناس هايدروفيليا. 